Journal of Teacher Education for Sustainability, vol. 18, no. 1, pp. 84-94, 2016

\title{
The Effect of Professional Development on Teacher Efficacy and Teachers' Self-Analysis of Their Efficacy Change
}

\author{
Julia H. Yoo \\ Lamar University, USA
}

\begin{abstract}
The current study examined the effect of an online professional development learning experience on teachers' self-efficacy through 148 (Male=22; Female=126) K-12 teachers and school educators. The Teachers' Self-Efficacy Scale (TSES) developed by TschannenMoran and Woolfolk Hoy (2001) was administered twice with a five-week gap. Additionally, all participants' descriptive self-analysis of their own score change was examined to analyze teachers' attributions of their self-efficacy change. Both quantitative and qualitative methodologies were used to analyze the data. The findings indicated that teacher efficacy increased as a result of their online professional development experience. Participants' self-analysis of their efficacy change provided some possible explanations for mixed reports for the influence of experience on teacher efficacy.

Keywords: teacher efficacy, teacher reflection, self-efficacy change, teacher professional development for sustainable development

The aim of this study is to investigate the effect of professional development on teacher efficacy and how teachers interpret their efficacy change. The sense of selfefficacy has been widely studied in the field of education as it has been recognized as an important factor that influences student achievement and behavior (Skaalvik \& Skaalvik, 2007; Tschannen Moran \& Woolfolk Hoy, 2001). Within the realm of social-cognitivism, Albert Bandura (1977) identified the concept of self-efficacy as missing, yet an important factor in his seminal publication, "Self-efficacy: Toward a Unifying Theory of Behavioral Change." Self-efficacy is defined as individuals' beliefs and judgments of their capabilities to manage and execute necessary courses of action (Bandura, 1997). The concept of teacher efficacy soon grew out of Bandura's self-efficacy, and a group of researchers from RAND, which is a nonprofit research organization, made an early effort in defining teacher efficacy (Armor, D., Conroy-Oseguera, P., Cox, M., King, N., McDonnell, L., Pascal, A., Pauly, E., \& Zellman, G., 1976; Berman, McLaughlin, Bass, Pauly, \& Zellman, 1977).
\end{abstract}




\section{Literature Review}

The concept of a teacher's self-efficacy refers to what he or she can do, and this area of research can be broadly categorized into three. First, this line of research reported the effect of teacher efficacy on students. Research has shown that a teacher's judgment of how much he or she can do affects student learning due to its impact on instructional choice (Ashton \& Webb, 1986; Bandura, 1997; Guskey, 1988; Ross, 1998) and persistence (Dembo \& Gibson, 1985; Soodak \& Podell, 1994; Woolfolk, Rosoff, \& Hoy, 1990). For instance, efficacious teachers tend to maintain high levels of student engagement (Good \& Brophy, 2003), and spend more time with struggling students by perceiving them as teachable with extra attention (Gibson \& Dembo, 1984). Wolters and Daugherty (2007) even suggested a correlation between teacher efficacy and mastery goal oriented classrooms they create in their classrooms. In a recent empirical study, Fackler and Malmberg (2016) showed a correlation between teacher efficacy and student learning achievement, and claimed a universal pattern in fourteen OECD countries.

Researchers also examined teacher efficacy in contexts or conditions in which a teacher performs tasks. Many teacher efficacy researchers commonly include school environment characteristics or job satisfaction with their perceived work environment as contextual factors. For example, teachers with low self-efficacy tend to show higher stress that is associated with their profession (Betoret, 2006), and it is also closely related to job satisfaction and teacher burnout (e.g., Klassen \& Chiu, 2010; Skaalvik \& Skaalvik, 2007). The reported findings regarding the close link between teacher efficacy and contextual variables are perhaps due to the nature of teacher efficacy that is context specific (Bandura, 1977; Tschannen-Moran \& Woolfolk Hoy, 2001).

Third, many researchers studied teacher efficacy with a teacher's own demographic factors including teaching grade level and years of teaching experience. By conducting a study involving preschool to high school teachers, Wolters and Daugherty (2007) reported an inversely related correlation between teacher efficacy and their grade level they teach. As an antecedent of teacher's self-efficacy, teaching experience in this line of research has been extensively studied. Although many researchers have reported the positive effects of teacher efficacy on student learning and teaching, mixed results have been found regarding the change of teacher efficacy over time (e.g., Ghaith \& Yaghi, 1997; Woolfolk Hoy \& Burke Spero, 2005). While Bandura (1997) believed that the sense of efficacy remains somewhat stable, Tschannen-Moran et al. (1998) reported that teacher efficacy could either solidify over time or change with their experience in teaching.

In spite of the mixed repots on the efficacy change over time, there is a need for the continued scholarly interest in teacher efficacy because it provides important information, which deals with teacher quality and sustainability. The high correlation between the quality of a teacher and student performance is a widely accepted notion, and thus the focus on teacher quality has had a long history in the field of education. In 1983, the National Commission on Excellence in Education called for a national attention to increasing a quality teacher workforce in a report called, A Nation at Risk. Spurred by the report, many educators, policymakers, scholars in the field have been putting efforts for improving teaching force. National Council on Teacher Quality and National Board for Professional Teaching Standards are some of the good example organizations that embodied the idea, and the need and importance of more rigorous standards and accountability for teachers continue to get emphasized. 
In accordance with the call for highly qualifying teachers in the field, National Commission on Teaching and America's Future (1996) emphasized the need for highquality continuing education, and education schools have paid attention to strengthening continuing education for teachers through master's programs (Putnam \& Borko, 2000). Consequently, the percentage of teachers who either hold or seek master's degree in education has only risen. According to the Council of Graduate Schools (2005), during the academic year of 2008 and 2009, the field of education remains as the discipline that awarded the most number of master's degrees, which is $23.8 \%$ of all graduate students. More recent report shows that the percentage of teachers who have either a master's or higher degree increased up to 38 (National Center for Education Statistics, 2012).

While the number of teachers who hold master's degrees and the emphasis on increasing teacher quality through professional development education has increased in various forms whether on campus or online, there continues to be a scarcity of research specific to innovative programs (Tom, 1999), such as fast growing online professional development programs. With the growing population of teachers who actively seek advanced degrees or professional continuing education opportunities, there is a need to examine how this continuing education affects teacher efficacy. More careful examination of how teaching experience affects teachers' self-efficacy is needed, especially with the changing demographics of teaching workforce (Klassen \& Chiu, 2010). Most of the existing literature on teacher efficacy has looked at teaching experience simply as a number of years in teaching. In particular, little attention has been given to how teacher efficacy evolves as a result of professional enhancement programs or through teachers' own reflection within the context.

Therefore, the purpose of this study was to examine teacher efficacy change using the Teachers' Self-Efficacy Scale (TSES) developed by Tschannen-Moran and Woolfolk (2001). Two research questions guided this study:

1. How does teacher efficacy change with an online professional development experience?

2. What are the teachers' attributions of their increased or decreased sense of self-efficacy?

\section{Method}

\section{Participants}

A total of 148 teachers and school educators who were enrolled in an online professional development program participated in this study. Although participants resided in various locations, at the time of their participation, they were taking an advanced Master's degree program at a state university's college of education. They came from various grade levels of teaching (29.7\% high school, $25 \%$ middle school, $35.1 \%$ elementary school, $6.8 \%$ kindergarten, $3.4 \%$ unknown). Female participants were predominant $(85.1 \%)$, and the following races and ethnicities were represented in the sample: $63.5 \%$ White/Caucasian, 17.6\% African American, 7.4\% Hispanic, 3.4\% American Indian/ Alaskan, 2\% Asian/Pacific Islander, and 6.2\% Other or Unknown. Participants' average age was $36.94(M d n=36, \mathrm{SD}=9.27)$, and their average year of teaching was $8.77(M d n=7$, $\mathrm{SD}=6.29)$. 


\section{Measure}

Teachers' Sense of Efficacy Scale (TSES), developed by Tschannen-Moran and Woolfolk Hoy (2001), is comprised of three subscales: Instructional Strategies, Student Engagement, and Classroom Management. A total of twenty-four items are rated on a 9-point Likert scale, one indicating nothing and nine indicating a great deal. The instrument has been widely used in the education field to assess teacher competence of using a variety of instructional and assessment strategies in their teaching contexts. Prior to completing the professional development session, the participants were asked to fill out the teacher efficacy scale, TSES. Post survey was sent out for them to fill out upon completion of the online learning session. For the teacher efficacy self-analysis, participants were asked to write down their self-analysis of efficacy change by comparing their pre and post questionnaire responses. All responses were collected online. Thus, there was no face-to-face contact with the researcher. The following instruction was given to all participants at the end of their professional development learning: add your scores for each subscale of TSES, and analyze your sense of self-efficacy, especially by comparing your scores from the beginning of your learning and now.

\section{Treatment}

The professional development consisted of five-week online learning module, which was broken down into weekly learning so that participants could receive constructive feedback from their professional learning coaches along the way. In multiple ways, the learning module contributed to the four sources of efficacy identified by Bandura (1997): mastery experiences, vicarious experiences, social persuasion, and physiological and affective states. First, for mastery experience, participants were introduced to effective instructional strategies to engage students through motivational theories with classroom application strategies. Theoretical part of the participants' learning includes online tutorials to watch and scholarly journals and books for reading. Over the period of five weeks, the participants were involved in applying motivational theories and concepts in their classrooms through various learning mediums, such as online discussions with peers, readings of current research on the topic, and applying tasks of the learned materials. Second, for vicarious experiences, participants were given tasks to observe their colleagues on campus bringing about student learning, and to observe an exemplary teacher's classroom and see how she engaged students in learning by using various instructional strategies. Third, for social persuasion, participants were given encouragement and appropriate feedback during their professional development learning experiences. Fourth, for physiological and affective states, participants were coached to make abstract and big ideas into more concrete and smaller chunks because feelings of stress and anxiety negatively affect teacher efficacy. Through weekly online discussion forums, participants were also given ample opportunities to share their stressful situations along with possible solutions or actual cases where they resolved difficult cases amongst each other. 


\section{Analysis}

To explore the first research question on the effect of online professional development session, a paired T-test and one-way ANOVA were conducted with three dimensions of teacher efficacy (instructional strategies, classroom management, and student engagement) along with their years of professional experience, grade level they teach, and sex. Constant comparison method (Glaser \& Strauss, 1967) was used for the second research question in order to analyze participants' self-description of their efficacy change.

\section{Results}

To explore the main effect of the online professional development session on teacher efficacy, a paired samples t-test was conducted in each of the three dimensions of teacher efficacy: Instructional Strategies, Classroom Management, and Student Engagement. There was a significant difference in scores for pre $(\mathrm{M}=7.46, \mathrm{SD}=.85)$ and post $(\mathrm{M}=8.08, \mathrm{SD}=.79)$ scores of instructional strategies; $\mathrm{t}(147)=-13.92, \mathrm{p}=.05$. A significant score difference was found for pre $(M=7.64, S D=.99)$ and post $(M=8.15$, $\mathrm{SD}=.83)$ scores of classroom management; $\mathrm{t}(147)=-9.57, \mathrm{p}<.001$. Also, there was a significant difference in scores for pre $(\mathrm{M}=7.08, \mathrm{SD}=.07)$ and post $(\mathrm{M}=7.90, \mathrm{SD}=.07)$ scores of student engagement (see Table 1).

Table 1

Comparisons of Group Means and Standard Deviations for Teacher Efficacy Scale Score

\begin{tabular}{lcccc}
\hline \multirow{2}{*}{ Scale } & \multicolumn{2}{c}{ Pre } & \multicolumn{2}{c}{ Post } \\
\cline { 2 - 5 } & $M$ & $S D$ & 64.63 & SD \\
\hline TSES_IS & 59.67 & 6.82 & 63.22 & 6.31 \\
\hline TSES_SE & 56.68 & 7.02 & 65.18 & 6.65 \\
\hline TSES_CM & 61.09 & 7.95 & C.
\end{tabular}

Note. IS = Instructional Strategy; SE = Student Engagement; $\mathrm{CM}=$ Classroom Management.

These results suggest that online professional development education does have a positive effect on teacher efficacy. However, one-way ANOVA analyses revealed no significant differences at $p<.05$ for all three dimensions of teacher efficacy against the independent variables of sex and grade level they teach.

\section{Descriptive Data Analyses}

Regarding the second research question, there were three emerging themes for teacher efficacy change: professional enhancement, frame of reference change, and learned helpless (see Table 2). 
Table 2

Attribution to Teacher Efficacy Change - Themes, and Example Quotes from Participants

\begin{tabular}{|c|c|c|}
\hline Definition & Example quotes & \\
\hline \multirow{2}{*}{$\begin{array}{l}\text { Theme 1: } \\
\text { Professional } \\
\text { enhancement }\end{array}$} & \multirow{2}{*}{$\begin{array}{l}\text { Teachers' knowledge } \\
\text { gain through learning } \\
\text { or positive outcomes }\end{array}$} & $\begin{array}{l}\text { I love knowing that I can set goals for myself as a } \\
\text { learner and a teacher, and meet them. }\end{array}$ \\
\hline & & $\begin{array}{l}\text { I learned so many concrete strategies about student } \\
\text { engagement and have been able to apply them into } \\
\text { my instruction throughout my learning. }\end{array}$ \\
\hline \multirow[t]{2}{*}{$\begin{array}{l}\text { Theme 2: } \\
\text { Frame of } \\
\text { reference } \\
\text { change }\end{array}$} & \multirow[t]{2}{*}{$\begin{array}{l}\text { Teachers' adjustment } \\
\text { of their own judg- } \\
\text { ment or evaluation } \\
\text { system }\end{array}$} & $\begin{array}{l}\ldots \text { on the first time around I scored myself lower } \\
\text { because I was unsure. After learning about all the } \\
\text { instructional strategies, I see so many things... I } \\
\text { believe this made me feel more confident in those } \\
\text { areas. }\end{array}$ \\
\hline & & $\begin{array}{l}\text { At the end of my five-week learning... I think I was } \\
\text { over confident and not truly understanding all that } \\
\text { was involved the first week of my learning. }\end{array}$ \\
\hline \multirow[t]{2}{*}{$\begin{array}{l}\text { Theme 3: } \\
\text { Learned } \\
\text { belplessness }\end{array}$} & \multirow[t]{2}{*}{$\begin{array}{l}\text { Teachers' repeated } \\
\text { unsuccessful or } \\
\text { negative experience }\end{array}$} & $\begin{array}{l}\text { In the district I teach, my hands are somewhat tied in } \\
\text { regards to curriculum. This may contribute to my } \\
\text { students' level of engagement to some degree. }\end{array}$ \\
\hline & & here is only so much a teacher can do. \\
\hline
\end{tabular}

The first theme, professional enhancement, is characterized as teachers' professional enhancement through knowledge gain or their successful outcomes. Many participants interpreted their increased teacher efficacy as the outcome of their knowledge gain through the online professional development opportunity. During the five weeks, participants were engaged in scholarly article discussion, forming learning communities with their colleagues, and classroom instruction application exercises. Developing a solid foundation of theories and concepts through an online professional development platform seemed to positively affect participants' efficacy as teachers. Below are some example self-analysis comments under this theme:

I did not expect such change [of teacher efficacy]. I really thought as I was completing the questionnaire that my scores would be the same. After I tallied my points, I looked back at my week 1 scores and I have increased in all three areas... I believe the reason I feel so good about my teaching abilities is because I feel I've been given some very useful information and tools that I can apply in class... I love knowing that I can set goals for myself as a learner and a teacher, and meet them. That gives me great satisfaction. - Female, middle school teacher with 10 year of teaching experience

I believe that the reason the increase [of teacher efficacy] is so high is that I learned so many concrete strategies about student engagement and have been able to apply them into my instruction throughout my learning. - Female, middle school teacher with 1 year of teaching experience

Another emerging theme, frame of reference change, is characterized as teachers' adjustment of their own judgment or evaluation system, which seems to be associated with experience and knowledge gain. For their teacher efficacy score change, many participants believed that it was due to the fact that their awareness of learning and 
teaching has changed over time. It is noteworthy that this frame of reference change was applied to both teacher efficacy increase and decrease. Below is an example selfanalysis comment:

My scores went up quite a bit. I believe maybe on the first time around I scored myself lower because I was unsure. After learning about all the instructional strategies, I see so many things. I actually do apply some in my own classroom. I believe this made me feel more confident in those areas. - Male, elementary school teacher with 7 year of teaching experience

Interestingly, a similar self-analysis of efficacy change was also made from participants to interpret their either same or decreased efficacy. Below are example selfanalysis comments:

After looking at my scores from the first week, all my scores have gone down. Maybe I was scoring myself higher than I am or maybe my frame of mind is different... - Female, elementary school teacher with 4 year of teaching experience

I scored 70 points originally and only 64 points at the end of my five-week learning. I am not sure what factors contributed to the decrease but my scores were lower in each area. I think I was over confident and not truly understanding all that was involved the first week of my learning... Usually the more you learn about a concept, the more you realize your deficiencies and I guess this is what happened. - Female, elementary school teacher with 20 year of teaching experience

Finally, the third emerging theme, learned helpless, refers to teachers' repeated unsuccessful or negative experience that inversely affects their teacher efficacy. Many participants said that their newly acquired pedagogical knowledge is important. However, although they believed that their teacher efficacy is affected by their capability and skills from the knowledge base, there are other external factors that also influence their efficacy, such as curriculum guidelines, student aptitudes, socio-economic status around the school, etc. Participants especially seemed to be frustrated with these exterior factors because they felt that they had no control over such factors. Below are example self-analysis comments under this theme:

... I find it odd that the questionnaire indicates that Student Engagement is my weakest area. I assumed that with the instructional strengths I portray, my students' levels of engagement would have been high. In the district I teach, my hands are somewhat tied in regards to curriculum. This may contribute to my students' level of engagement to some degree. - Female, elementary school teacher with 13 year of teaching experience

I believe my scores changed very little because I have been a teacher for seven years to this point. If I were a new teacher, I believe the scores would have changed tremendously... All these articles put all the pressure on teachers. There is only so much a teacher can do. - Male, high school teacher with 7 year of teaching experience. 


\section{Discussion}

The current investigation is part of a larger study of teacher efficacy and the effects of professional development programs for teachers and school educators. With the growing number of online continuing education programs, there is a dire need to examine how teacher efficacy develops and evolves with such programs. In particular, the existing literature on teacher efficacy looked at teachers' experience as a whole without dissecting it. In other words, an examination of the relationship between teacher efficacy and the degree to which teachers are involved with their professional development is of interest because even though experience is vital, one can become an experienced non-expert regardless of the years of experience (Bereiter \& Scardamalia, 1993). Thus, the main focus of this study was to examine teacher efficacy change through an online professional development, and to identify teachers' attributions of their increased or decreased sense of self-efficacy.

The current research findings have shown that teachers' professional development effort does have a positive effect on teacher efficacy. In addition, the descriptive selfanalyses of teacher efficacy in this study have shown that gaining new knowledge was generally positively related to teacher efficacy. These findings are aligned with a recent empirical study with mathematics teachers (Ross \& Bruce, 2007), even though professional development delivery modality was different from this study. The positive effect of professional development on teacher efficacy is not surprising in that strong teacher training programs are known to be positively associated with teacher efficacy (Kazempour \& Sadler, 2015; Tuchman \& Isaacs, 2011).

One of the notable findings of this study was the frame of reference change through professional development experiences. Participants said that it could either positively or negatively affect their teacher efficacy. For instance, after gaining more knowledge about contents and instructional strategies, they found themselves either overrated themselves with overconfidence or underrated with the feeling of uncertainty. Consistent with Bandura's (1997)'s view, the findings in this study showed overall positive teacher efficacy change with an additional training that is designed to aid teaching experience. A closer look at individual teacher's years of teaching experience, however, did not show any meaningful teacher efficacy change. This finding is consistent with some previous studies (Brousseau, Book, \& Byers, 1988; Ghaith \& Yaghi, 1997; Green-Wood, Olejnik, \& Parkay, 1990; Guskey, 1987; Klassen \& Chiu, 2010; Wolters \& Daugherty, 2007).

\section{Conclusion}

As UNESCO (2005) addressed in its decennial report called, guidelines and recommendations for reorienting teacher education to address sustainability, education is at the center of creating a more sustainable future. Accordingly, UNESCO placed an emphasis on teacher education, which is a driving force for sustainability in its broadest sense because teachers are in the place to shape better educated future generations. The scholarly effort of supporting education for sustainable development through teacher education programs has been active (e.g., McKeown, 2014). Among many principles and practices for teachers, Nolet (2015) claimed that critical thinking and metacognition are critical because teaching for sustainability places an emphasis on problem solving 
through cognitive processes rather than specific content. Therefore, reflecting and carefully examining one's own teacher efficacy is essential, especially in the global context for sustainability (Gunzelmann, 2013).

The current study extends previous research by examining professional development effects on teacher efficacy along with their self-analysis of efficacy change. The scholarly significance of the current study lies in its timeliness examination in this line of study because little attention has been given to teacher professional development especially in an online setting. Moreover, the findings of this study provide evidence of teachers' self-reflection on their efficacy change. The results combined with further research could perhaps provide a fuller understanding of how teacher efficacy develops and evolves. This research will help better understand how teachers grow as professionals, which will then enable us to develop innovative forms of teaching and learning that can address students from diverse backgrounds, including learners with academically and economically disadvantaged learners.

In order to promote education for sustainable development, it is essential to periodically conduct empirical studies on teachers and teacher education programs in this rapidly changing environment. Perhaps, future studies can examine further regarding teacher efficacy and its change in an online learning environment with various professional learning methods. For instance, collaboration and mentoring have been reported to be effective in teacher education (Sachs, Fisher, \& Cannon, 2011), but their effect has not been investigated in an online environment.

\section{References}

Armor, D., Conroy-Oseguera, P., Cox, M., King, N., McDonnell, L., Pascal, A., Pauly, E., \& Zellman, G. (1976). Analysis of the school preferred reading programmes in selected Los Angeles minority schools. (REPORT NO: R-2007-LAUSD.) Santa Monica, CA: The Rand Corporation. (ERIC Document Reproduction Service No. 130 243).

Ashton, P. T., \& Webb, R. B. (1986). Making a difference: Teachers' sense of efficacy and student achievement. New York, NY: Longman.

Bandura, A. (1991). Self-efficacy mechanism in physiological activation and healthpromoting behavior. In J. Madden, IV (Ed.), Neurobiology of learning, emotion and affect (pp. 229-270). New York: Raven.

Bandura, A. (1997). Self-efficacy: The exercise of control. New York, NY: Freeman.

Bandura. A. (1977). Self-efficacy: Toward a unifying theory of behavioral change. Psychological Review, 84, 191-215.

Berman, P., McLaughlin, M., Bass, G., Pauly, E., \& Zellman, G. (1977). Federal programs supporting educational change. Vol. VII factors affecting implementation and continuation (Report No. R-1589/ 7-HEW) Santa Monica, CA: The Rand Corporation. (ERIC Document Reproduction Service No. 140 432).

Bereiter, C., \& Scardamalia, M. (1993). Surpassing ourselves: An inquiry into the nature and implications of expertise. La Salle, IL: Open Court.

Brousseau, B., Book, C., \& Byers, J. (1988). Teacher beliefs and the cultures of teaching. Journal of Teacher Education, 39(6), 33-39.

Council of Graduate Schools. (2005). Master's education: A guide for faculty and administrators. Washington, DC: Council of Graduate Schools. 
Dembo, M. H., \& Gibson, S. (1985). Teachers' sense of efficacy: An important factor in school improvement. Elementary School Journal, 86, 173-184.

Fackler, S., \& Malmberg, L.-E. (2016). Teachers' self-efficacy in 14 OECD countries: Teacher, student group, school and leadership effect. Teaching and Teacher Education, 56, 185-195.

Ghaith, G., \& Yaghi, H. (1997). Relationships among experience, teacher efficacy, and attitudes toward the implementation of instructional innovation. Teaching and Teacher Education, 13, 451-458.

Gibson, S., \& Dembo, M. H. (1984). Teacher efficacy: A construct validation. Journal of Educational Psychology, 76, 569-582. doi: 10.1037/0022-0663.76.4.569.

Glaser, B. G., \& Strauss, A. L. (1967). The discovery of grounded theory: Strategies for qualitative research. Chicago: Aldine.

Good, T. L., \& Brophy, J. E. (2003). Looking in the classroom (9 $9^{\text {th }}$ ed.). Boston: Allyn \& Bacon.

Greenwood, G., Olejnik, S., \& Parkay, F. (1990). Relationships between four teacher efficacy belief patterns and selected teacher characteristics. Journal of Research and Development in Education, 23, 102-107.

Guskey, R. (1988). Teacher efficacy, self-concept, and attitudes toward the implementation of instructional innovation. Teaching and Teacher Education, 4, 63-69.

Kazempour, M., \& Sadler, T. D. (2015). Pre-service teachers' science beliefs, attitudes, and self-efficacy: a multi-case study. Teaching Education, 26(3), 247-271. http://dx.doi.org/10.1080/10476210.2014.996743

Klassen, R. M., \& Chiu, M. M. (2010). Effects on teachers' self-efficacy and job satisfaction: Teacher gender, years of experience, and job stress. Journal of Educational Psychology, 102, 741-756. doi: 10.1037/a0019237.

National Board for Professional Teaching Standards. (1989). What teachers should know and be able to do. Detroit, MI: NBPTS.

National Center for Education Statistics [NCES] (2012). Digest of Education Statistics, 2011 (NCES 2012-001), Introduction and Chapter 2: U.S. Department of Education, National Center for Education Statistics, Schools and Staffing Survey, Teacher Data Files, 2007-08.

Putnam, R., \& Borko, H. (2000). What do new views of knowledge and thinking have to say about research on teacher learning? Educational Researcher, 29(1), 41-45.

Ross, J. A. (1998). The antecedents and consequences of teacher efficacy. In J. Brophy (Ed.), Advances in research on teaching, vol. 7 (pp. 49-73). Greenwich: JAI.

Ross, J. \& Bruce, C. (2007). Professional development effects on teacher efficacy: Results of randomized field trial. The Journal of Educational Research, 101(1), 50-60, DOI: 10.3200/JOER.101.1.50-60.

Sachs, G. T., Fisher, T., \& Cannon, J. (2011). Collaboration, mentoring and co-teaching in teacher education. Journal of Teacher Education for Sustainability, 13(2), 70-86.

Skaalvik, E. M., \& Skaalvik, S. (2007). Dimensions of teacher self-efficacy and relations with strain factors, perceived collective teacher efficacy, and teacher burnout. Journal of Educational Psychology, 99(3), 611-625. doi: 10.1037/0022-0663.99.3.611.

Soodak, L. C., \& Podell, D. M. (1994). Teachers' thinking about difficult-to-teach students. Journal of Educational Research, 88, 44-51. 
Tschannen-Moran, M., Woolfolk Hoy, A. (2001). Teacher efficacy: Capturing an elusive construct. Teaching and Teacher Education, 17, 783-805.

Tuchman, E., \& Isaacs, J. (2011). The influence of formal and informal formative preservice experiences on teacher self-efficacy. Educational Psychology, 31(4), 413433. http://dx.doi.org/10.1080/01443410.2011.560656

UNESCO (2005). Guidelines and recommendations for reorienting teacher education to address sustainability. Education for sustainable development in action. Technical Paper no. 2. Paris: UNESCO. Retrieved from http://unesdoc.unesco.org/images/ 0014/001433/143370e.pdf

Wolters, C. A., \& Daugherty, S. G. (2007). Goal structures and teachers' sense of efficacy: Their relation and association to teaching experience and academic level. Journal of Educational Psychology, 99(1), 181-193. doi: 10.1037/0022-0663.99.1.181.

Woolfolk Hoy, A., \& Burke Spero, R. (2005). Changes in teacher efficacy during the early years of teaching: A comparison of four measures. Teaching and Teacher Education, 21, 343-356.

Correspondence concerning this paper should be addressed to Julia H. Yoo, Ph. D, Lamar University, P.O. Box 10034, Beaumont, TX 77710, USA. Email: julia.yoo@lamar.edu 